Kong. Res. J. 4(2): 32-38, 2017

ISSN 2349-2694

Kongunadu Arts and Science College, Coimbatore.

\title{
ETHNOMEDICINAL PLANTS USED BY THE IRULA TRIBALS OF PALAMALAI HILLS, SOUTHERN WESTERN GHATS OF COIMBATORE, TAMIL NADU, INDIA
}

\author{
Venkatachalapathi, A. and S. Paulsamy* \\ Department of Botany, Kongunadu Arts and Science College, Coimbatore - 641029. \\ *E.mail: paulsami@yahoo.com
}

\begin{abstract}
The present study is aimed to document the ethnomedicinal plants used for various ailments by the Irula tribes of Palamalai hills, Southern Western Ghats of Coimbatore, Tamil Nadu, India. A total number of 53 plants species belonging to 50 genera and 32 families used by them as herbal medicines to treat several common diseases such as skin diseases, dysentery, cough and cold, cuts and wounds, etc. were documented. Among the plant species Herbs were the primary source of medicine (40\%) followed by trees (28\%), shrubs $(15 \%)$ and climbers $(17 \%)$ and leaves were mostly used (35\%) for various illness followed by whole plant $(18 \%)$, root $(13 \%)$, stem $(7 \%)$, bark and rhizome $(6 \%)$ and seeds and tubers $(4 \%)$. Most of the medicine prescription by healers is decoction. Therefore, it is suggested to take-up pharmacological and phytochemical studies to evaluate the species to confirm the traditional knowledge of Irulas on medicinal plants.
\end{abstract}

Keywords: Ethnobotany, Irulas, Palamalai hills, Western Ghats.

\section{INTRODUCTION}

Ethnobotany word is made from two words ethno and botany and the term was coined by John William Harshberger in the 1896. Ethnobotany is the study of people and study of plants; this is represented good relationship between wild plants (Herbs, Shrubs and Trees) and tribal's. Ethnobotany is the branch of Ethnobiology and complete information about plants and their medicinal uses is given by ethnobotanical studies (Jitin, 2013). India is rich in ethnic diversity and indigenous knowledge that has resulted in exhaustive ethnobotanical studies. There are over 537 different aboriginal groups in India with extensive knowledge of plants (Jain, 1991). Herbal medicine is widely practiced throughout the world from time immemorable. These medicines are safe and environment friendly. The World Health Organization (WHO) defines traditional medicine as practices, knowledge and belief systems which uses minerals, plants and animal based remedies, spiritual therapies and exercises to prevent, treat and maintain well being (WHO, 2003). According to the WHO, about $80 \%$ of the population of the world depends on traditional medicine, mostly herbal remedies, for their primary health care needs (Muthu et al., 2006). In the developed countries people are seeking for herbal medicine because of their scarcity side effects compared to the synthetic drugs. According to WHO 70 to 90 percent of world population especially from developing countries, use plant remedies for their health care (Belachew, 1984; Nair and Nathan, 1998). Developing countries like India, Pakistan and
China have identified potential usage of medicinal plants, and integrated them in to their overall health care system (Andrew, 1982).

The indigenous traditional knowledge of medicinal plants of various ethnic communities, where it has been transmitted orally for centuries is fast disappearing from the face of the earth due to the advent of modern technology and transformation of traditional culture (Ganesan et al., 2004; Rajadurai et al., 2009). The recent reports have indicated that, $25 \%$ of the modern drugs are derived from the extract of medicinal plants. It is estimated that $70 \%$ to $80 \%$ of the people worldwide rely chiefly on traditional healthcare system and largely on herbal medicines (Robert and John, 1983; Shanley and Luz, 2003; Kaur et al., 2011). Until recently, plants were important sources for the discovery of novel pharmacologically active compounds, with many blockbuster drugs being derived directly or indirectly from plants (Newman and Cragg, 2007; Li, 2010).

Irulars are small tribal community in the part of Dravidian language group which is spoken in south eastern India. They belong to the Negrito (or Negroid) race which is one of the six main ethnic groups that add to the racial mosaic of India (Deepa et al., 2002). The origin of the word "Irula" is not clear. Some surmise that, it is derived from the Tamil word "Irual" implying the dark complexion of the Irula, often being spotted by villagers as distinct silhouettes in the forests and supporting their local name, the Forest People (Fuchs, 1973). They do not practice agriculture and therefore, fully depend on 
forest produces and wild animals. Other occupations of the Irulars include intermittent farm labour and the legendary profession of snake charming (Venkatachalapathi et al., 2015; 2016). In recent years some researchers have reported various medicinal plants used by Irula tribals in Anaikatty hills, Siruvani hills and Maruthamalai hills of Coimbatore district (Palanisamy, 1993; Balasubramanian et al., 1997; Nikkitha, 1999; Hamasavalli, 2001; Karthikeyani, 2003; Senthilkumar, 2004; Senthilkumar et al., 2006; Geetha et al., 2007; Paulsamy, 2011; Tamilselvi et al., 2016). Therefore, the aim of the study was, to documentation of traditional knowledge of utilization of medicinal plants used by Irula tribes for various ailments in Palamalai hills of Coimbatore district, Tamil Nadu.

\section{MATERIALS AND METHODS}

\subsection{Study area}

The present work was undertaken in the Palamalai hills located in the Coimbatore district of Tamil Nadu, South India. Palamalai is an offshoot of the Eastern Ghats geographically contiguous with the Billigrirangaa hills range as they reach out to merge with the Western Ghats at Nilgiris. It lies at an altitude of $1839 \mathrm{~m}$ above mean sea level and an attitude of $1400 \mathrm{~m}$ on the Western Ghats (Fig. 1). The ethnobotanical survey was carried out during October 2009 to March 2010 among Irula population residing in this area.

\subsection{Data collection}

The data on medicinal plants was recorded through interview, discussion and field observation with knowledgeable elder people using standard methods adopted by Jain (1991) and Jain and Goel (1995). Out of 19, 10 were male and 9 female respondents under the age group of 35 to 70 years. The information about plants and their local names, parts of plant used for preparation of drug and mode of administration were documented in the field survey and it was confirmed by cross-checking with respondents and also with the already existing literature.

The collected plant species were identified with help of The Flora of Presidency of Madras (Gamble and Fischer, 1915-1936) and confirmed by comparing authentic specimens in Madras Herbarium (MH) at Botanical Survey of India, Southern circle, Coimbatore and through recent floras and taxonomic revisions. The voucher specimens were deposited at the Department of Botany, Kongunadu Arts and Science College, Coimbatore, Tamil Nadu.

\section{RESULTS AND DISCUSSION}

The present study revealed the use of 53 species of plants distributed in 50 genera belonging to 32 families which were commonly used by Irula tribal healers of Palamalai hills, southern Western Ghats of Coimbatore district, Tamil Nadu for the treatment of 35 types of ailments. The prominent family was Fabaceae with 6 species, followed by Euphorbiaceae with 4 species, Caesalpiniaceae and Verbenaceae with 3 species each, Acanthaceae, Apocynaceae, Asclepiadaceae, Asteraceae, Lamiaceae, Malvaceae, Poaceae and Rutaceae, Solanaceae contributed with 2 species each and Aizoaceae, Amaranthaceae, Anacardiaceae, Aristolochiaceae, Boraginaceae, Caricaceae, Cleomaceae, Convolvulaceae, Cucurbitaceae, Liliaceae, Meliaceae, Mimosaceae, Myrtaceae, Papaveraceae, Piperaceae, Rhamnaceae, Sapindaceae, Vitaceae and Zygophyllaceae contributed with 1 species each. All the reported species were arranged alphabetically and provided the botanical name of the plant, family, specimen number, local (Tamil) name, life form, part (s) used, ailments treated and mode of administration (Table 1).

Herbs were the primary source of medicine (40\%) followed by trees (28\%), shrubs $(15 \%)$ and climbers (17\%) (Fig. 2). The frequent use of among the indigenous communities is a result of wealth of herbaceous plants in their environs (Tabuti et al., 2003; Uniyal et al., 2006; Giday et al., 2010) and a Yercaud hills harbours more number herbs as compared to trees, shrubs and climbers (Parthipan et al., 2011). Among the different parts used, the leaves $(56 \%)$ were most frequently used for the preparation of medicine solely or in combination with other parts. It was followed by bark and whole plant ( $7 \%$ each), roots (6\%), fruit and seeds (5\% each), stem, flowers and latex (4\% each) and bulb (2\%) (Fig. 3). Many indigenous communities throughout the world also utilized mostly leaves for the preparation of herbal medicines (Teklehaymanot et al., 2007; Cakilcioglu and Turkoglu, 2010; Gonzalez et al., 2010). The reason why leaves were used mostly is that they are collected very easily than underground parts, flowers, fruits, etc. (Giday et al., 2009).

The preparation and utilization of plant parts were grouped in to five categories (Fig. 4). Of these, most commonly used method preparation was decoction (42\%) followed by paste (36\%) juice (12\%), powder (7\%) and raw (3\%). 


\section{Table 1. List of medicinal plant species used for their health care by Irula tribals of Palamalai hills, Western Ghats of Coimbatore district, Tamil}

Nadu.

\begin{tabular}{|c|c|c|c|c|c|c|}
\hline S. No. & Binomial Name & Local name & Family & Parts used & Medicinal uses & $\begin{array}{c}\text { Mode of } \\
\text { administration }\end{array}$ \\
\hline \multirow[t]{2}{*}{1} & Trees & & & & & \\
\hline & Aegle marmelos (Linn.) Corr. & Vilvam & Rutaceae & Leaf & Dyspepsia & Decoction \\
\hline \multirow[t]{2}{*}{2} & Albizia amara (Roxb.) B. Boivin. & Arapu & Mimosaceae & Flower and seeds & Piles & Paste \\
\hline & & & & & Diarrhea & Decoction \\
\hline 3 & Azadirachta indica A. Juss. & Vembu & Meliaceae & Bark & Stomach worms & Decoction \\
\hline \multirow[t]{2}{*}{4} & Carica papaya L. & Pappali & Caricaceae & Latex & Scorpion sting & Paste \\
\hline & & & & & Snake bites & Paste \\
\hline 5 & Emblica officinalis Gaertn. & Nellikkai & Euphorbiaceae & Fruit & Cold and cough & Decoction \\
\hline 6 & Mangifera indica $\mathrm{L}$. & Maamaram & Anacardiaceae & Leaf & Cracks & Paste \\
\hline \multirow[t]{2}{*}{7} & Pongamia pinnata (Linn.) Pierre. & Pungamaram & Fabaceae & Leaf & Ulcers & Decoction \\
\hline & & & & & Diabetes & Decoction \\
\hline 8 & Psidium guajava L. & Koiya & Myrtaceae & Leaf & Dysentery & Juice \\
\hline 9 & Pterocarpus marsupium Roxb. & Vengai & Fabaceae & Bark & Dysentery & Decoction \\
\hline 10 & Tamarindus indica $\mathrm{L}$. & Puliyamaram & Caesalpiniaceae & Fruit & Digestive & Raw \\
\hline \multirow[t]{2}{*}{11} & Tectona grandis Linn. f. & Tekkumaram & Verbenaceae & Leaf & Skin diseases & Paste \\
\hline & & & & & Ulcers & Decoction \\
\hline \multirow[t]{2}{*}{12} & Vitex negundo L. & Notchi & Verbenaceae & Flowers & Diarrhea & Decoction \\
\hline & & & & & Cardiac disorders & Decoction \\
\hline 13 & Wrightia arborea Mabberley. & Karupaalai & Apocynaceae & Bark & Kidney stones & Powder \\
\hline 14 & Wrightia tinctoria (Roxb.) R. Br. & Veppalai & Apocynaceae & Leaf & Headache & Paste \\
\hline 15 & Ziziphus mauritiana L. & Ilanthai & Rhamnaceae & Leaf & Wound healing & Paste \\
\hline \multirow[t]{2}{*}{16} & Shrub & Pirammathandu & Papaveraceae & Seed & Cracks at foot & Powder \\
\hline & Argemone mexicana L. & & & & & \\
\hline 17 & Calotropis gigantea (Linn.) R. Br. & Erukku & Asclepiadaceae & Latex & Wound healing & Paste \\
\hline \multirow[t]{2}{*}{18} & Cassia auriculata L. & Avarai & Caesalpiniaceae & Leaf & Scabies & Paste \\
\hline & & & & & Bone fractures & Paste \\
\hline \multirow[t]{2}{*}{19} & Cassia tora $\mathrm{L}$. & Tagarai & Caesalpiniaceae & Leaf & Leprosy & Decoction \\
\hline & & & & & Ulcers & Decoction \\
\hline 20 & Indigofera tinctoria $\mathrm{L}$. & Averi & Fabaceae & Root & Snake bites & Decoction \\
\hline 21 & Jatropha curcas L. & Kattu amanaku & Euphorbiaceae & Stem & Digestion & Juice \\
\hline 22 & Lablab purpureus (Linn.) Sweet. & Avarai & Fabaceae & Leaf & Ring worm & Paste \\
\hline 23 & Lantana camara L. & Unnichedi & Verbenaceae & Leaf & Cuts and wounds & Paste \\
\hline 24 & $\begin{array}{l}\text { Herbs } \\
\text { Ahutilon indicum (Iinn) Sweet }\end{array}$ & Thuthi & Malvaceae & Root & Fever & Decoction \\
\hline
\end{tabular}


Achyranthes aspera L.

Allium cepa L.

Andrographis echioides (Linn.) Nees.

Andrographis paniculata (Burm. f.)

Wall. ex Nees.

Bambusa arundinacea (Retz.) Roxb.

Cleome gynandra L.

Cynodon dactylon Dress.

Datura metel L.

Eclipta prostrata L.

Euphorbia hirta L.

Evolvulus alsinoides L.

Mollugo nudicaulis L.

Leucas aspera L.

Ocimum americanum L.

Phyllanthus amarus Schum. and Thonn.

Sida cordifolia L.

Solanum nigrum $\mathrm{L}$.

Tribulus terrestris L.

Trichodesma indicum L.

Tridax procumbens $\mathrm{L}$.

\section{Climbers}

Abrus precatorius L.

Aristolochia bracteolata Lam.

Cardiospermum halicacabum Linn.

Cissus quadrangularis L.

Clitoria ternatea $\mathrm{L}$.

Coccinia indica Wight and Arn.

Pergularia daemia (Forsk.) Chiov.

Piper nigrum L.

Toddalia asiatica L.

$\begin{array}{cc}\text { Naayuruvi } & \text { Amaranthaceae } \\ \text { Vengayam } & \text { Liliaceae } \\ \text { Gopuram thangi } & \text { Acanthaceae } \\ \text { Nilavembu } & \text { Acanthaceae }\end{array}$

Leaf
Bulb
Leaf
Bark

Leaf
Leaf
hole plant
Leaf
Leaf

Amman pacharisi

Vishnukranthi

Parpadakam

Kavil thumbai

Kinathupoondu

Aaduthinnappalai

\section{Mudakkathan}

Mungil
Veli Keerai
Arugampull
Oomethai
Karasilaganni

Tumbai

Nai thulasi

Kila nelli

Nilathuthi

Manathakkali

Nerunjimul

Kundumani

Perandai

Thuthi

Kovaikai

Veliparuthi

Kurumilagu

Poaceae
Cleomaceae
Poaceae
Solanaceae
Asteraceae

Convolvulaceae

Aizoaceae

Lamiaceae

Lamiacaeae

Euphorbiaceae

Malvaceae

Solanaceae

Zygophyllaceae

Boraginaceae

Asteraceae

Fabaceae

Aristolochiaceae

Sapindaceae

Vitaceae

Fabaceae

Cucurbitaceae

Asclepiadaceae

Kindu mullu

\begin{abstract}
Piperaceae
\end{abstract}

\section{Euphorbiaceae}

\section{Leaf}

Leaf

Leaf

Leaf

Leaf

Leaf

Leaf

Leaf

Fruit

Leaf

Leaf

Root

Whole plant

Whole plant

Stem

Whole plant

Leaf

Leaf

Seed
Dog bite

Boils

Fever

Fever

Skin diseases

Snake bite

Wound healing

Ear ache

Eye disorder

Respiratory troubles

Black hair

Skin diseases

Wound healing

Dysentery

Wound healing Boils

Bronchitis

Cold

Jaundice

Ear ache

Mouth sores

Cough

Diarrhea

Dysentery

Wound healing

$$
\text { Cough }
$$

Skin diseases

Snake bites

Swellings

Joints pains

Stomachache

Fever

Diabetes

Cold

Fever

Cough

Throat infection

Stomachache
Paste

Paste

Juice

Decoction

Paste

Paste

Paste

Juice

Juice

Juice

Paste

Paste

Paste

Decoction

Paste

Paste

Decoction

Decoction

Juice

Juice

Raw

Juice

Decoction

Decoction

Paste

Decoction

Decoction

Decoction

Paste

Paste

Decoction

Decoction

Powder

Decoction

Decoction

Powder

Powder

Decoction 


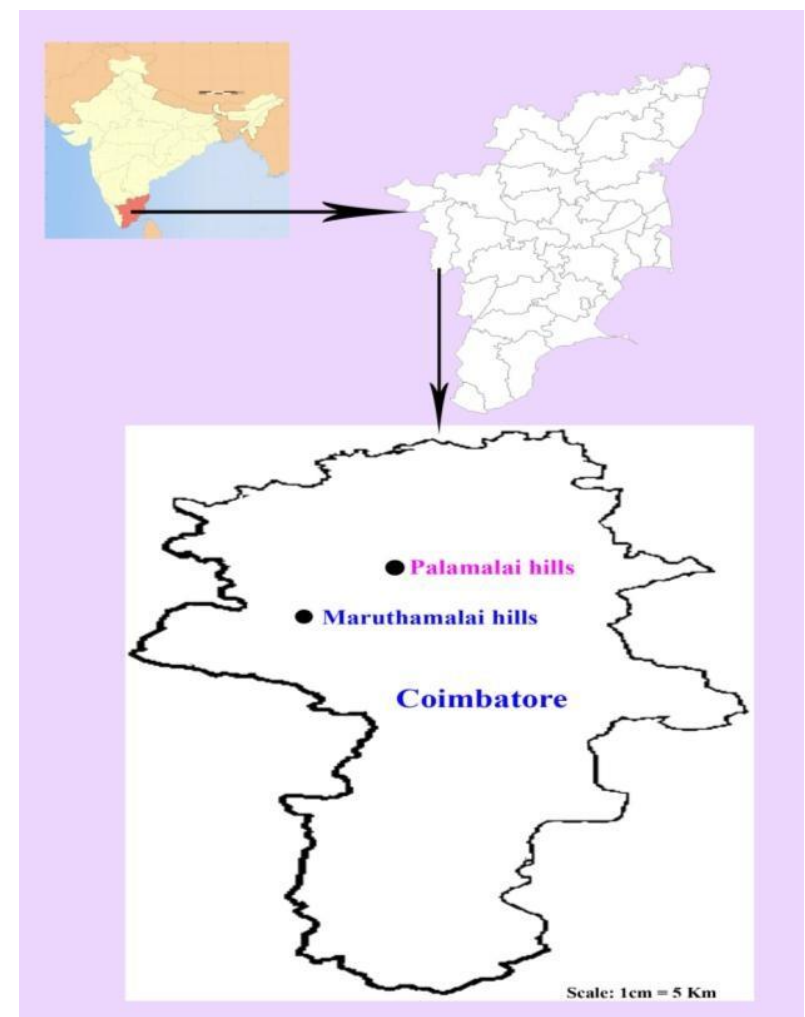

Fig. 1. Location of the study area of Palamalai hills.

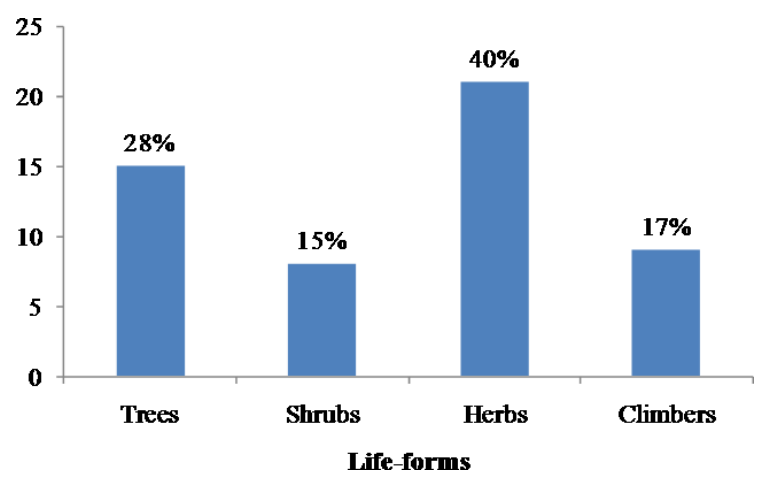

Fig. 2. Per-cent life-forms of medicinal plants used by Irulas in Palamalai hills.
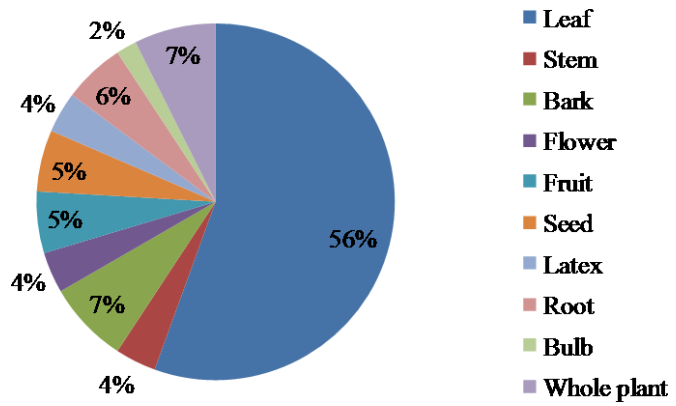

Fig. 3. Per-cent plant parts used for medicine preparation.

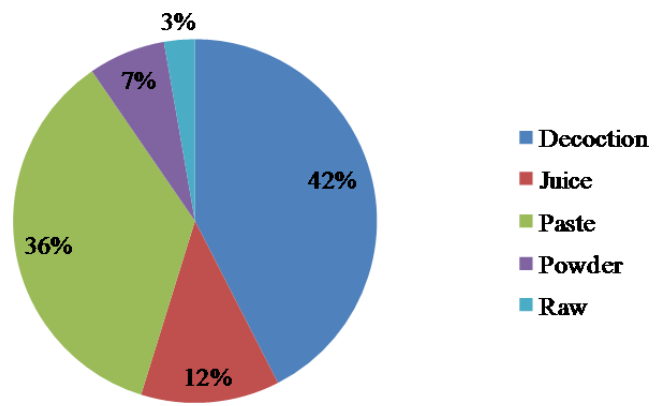

Fig. 4. Per-cent form of medicine preparation by Irula tribe.

Preparation of paste for the treatment of ailments is a common practice among the tribal communities in the world (Giday et al., 2007; Roosita et al., 2008; Giday et al., 2010). The paste was prepared by grinding the fresh or dried plant parts with oil or water. The powder was prepared by grinding of shade dried plant parts. The decoction was obtained by boiling the plant parts in water until the volume of the water reduced to minimum or required amount. The inhalation was done by the burning of plant parts and inhaled the smoke through nose or mouth (Roosita et al., 2008).

The ethnomedicinal studies evidently pointed out that, instead of trying to identify the active compounds and pharmacological actions of plants through massive collection of plants from natural sources, it is better to start investigating the efficacy of the plant based on their use in folk medicine, since most of the commercially proven drugs used in modern medicine were initially tried in crude form in traditional of folk healing practices (Fabricant and Fransworth, 2001).

\section{CONCLUSION}

All the enumerated plant species are very commonly used for various ailments by the Irula tribes of Palaalai hills, southern Western Ghats of Coimbatore district, Tamil Nadu. A few interesting observations made in the present study are: the use of Coccinia indica and Pongamia pinnata for diabetes, Vitex negundo for cardiac disorders, Carica papaya and Indigofera tinctoria for poisonous snake bites, Cardiospermum halicacabum for joints pains, Cassia auriculata for scabies and bone fractures. Although traditional medication is still practiced in this area, it is now fast disappearing due to modern life style. Hence, proper documentation and preservation of traditional skills and technology of medicinal plants is a vital necessity. Further investigations on 
pharmacological importance of these plants and their diversity may add new knowledge to the traditional medical and cultural systems.

\section{REFERENCES}

Andrew, T. (1982). Natural Foods and unconventional medical treatment. A bibliography on herbs and herbal medicines. Libraries Unlimited Inc. USA.

Balasubramanian, P., A. Rajasekaran and S.N Prasad, (1997). Folk medicine of the Irular of Coimbatore forests, Ancient Sci. Life 16(3): 222226.

Belachew, D. (1984). Ethiopian traditional herbal drugs: potentiality and appropriate utilization. $8^{\text {th }}$ International Conference of Ethiopian Studies. 763-6.

Cakilcioglu, U. and I. Turkoglu, (2010). An ethnobotanical survey of medicinal plants in Sivrice (Elazig-Turkey). J. Ethnopharmacol 132: 165-175.

Deepa, E.H., R. Viswanathan, R. Sangita, M.V. Usha Rani and P.P. Majumdar, (2002). Mitochondrial DNA diversity among five tribal populations of Southern India. Curr. Sci 83(2): 158-162.

Fabricant, D.S. and N.R. (2001). Fransworth, The value of plants used in traditional medicine for drug discovery. Environ Health Pers. 109: 6975.

Fuchs, S. (1973). Aboriginal tribes of Eastern India, Cosmo Publications, New Delhi,

Gamble, J.S. and C.E.C. (1915-1936). Fischer, Flora of the Presidency of Madras, Adlard and Sons Ltd., London.

Ganesan, S., N. Suresh and L. Kesavan, (2004). Ethnomedicinal survey of lower palni Hills of Tamil Nadu. Indian J. Trad. Know 3(3): 299-304.

Geetha, S., S. Poornima and J. Vaseegari, (2007). Studies on the Ethnobotany of Irulars of Anaikatty hills, Coimbatore District, College Sci India 1: 2-20.

Giday, M., Z. Asfaw and Z. Woldu, (2010). Ethnomedicinal study of plants used by Sheko ethnic group of Ethiopia. J. Ethnophrmacol 132: 75-85.

Giday, M., Z. Asfaw and Z. Woldu, (2009). Medicinal plants of the Meinit ethnic group of Ethiopia: an ethnobotanical study. J. Ethnopharmacol 124: 513-521.
Giday, M., T. Teklehaymanot, A. Animut and Y. Mekonnen, (2007). Medicinal plants of the Shinasha, Agew-awi and Amhara peoples in northwest Ethiopia. J. Ethnopharmacol 110: 516-525.

Gonzalez, J.A., M. Garcia-Barriuso and F. Amich, (2010). Ethnobotanical study of medicinal plants traditionally used in the Arribes del Duero, Western Spain. J. Ethnopharmacol 131: 343-355.

Hamasavalli, P. (2001). Ethnopharmacological studies of Irulas of Anaikatti hills, Coimbatore district, Tamil Nadu. M.Sc. Dissertation, Bharathiar University, Coimbatore, Tamil Nadu.

Harshberger, J.W. (1896). The purpose of ethnobotany. Bot. Gaz., 21: 146-158.

Jain, S.K. and A.K. Goel, (1995). A Manual of Ethnobotany (Scientific Publishers, Jodhpur).

Jain, S.K. (1991). Dictionary of Indian Folk Medicine and Ethno botany, Deep Publication, New Delhi.

Jitin, R. (2013). An ethnobotanical study of medicinal plants in Taindol Village, district Jhansi, Region of Bundelkhand, Uttar Pradesh. J. Med Plants 1(5): 59-71.

Karthikeyani, T.P. (2003). Ethno-medico-botanical studies of Irulars in Siruvani Hills, Coimbatore District, Tamil Nadu, India. Ph.D. Thesis, Bharathiar University, Coimbatore, Tamil Nadu.

Kaur, R., A. Sharma, R. Kumar and R. Kharb, (2011). Rising Trends towards Herbal Contraceptives. J Nat Prod Plant Resour 1(4): 5-12.

Li, P. (2010). Hot topic: Plant Natural Products in Drug Discovery Current Organic Chemistry. 14(16): 1669.

Muthu, C., M. Ayyanar, N. Raja and S. Ignacimuthu, (2006). Medicinal plants used is traditional healers in Kancheepuram District of Tamil Nadu, India. J. Ethnobiol Ethnomed 2: 43.

Nair, M. and G. Nathan, (1998). Medicinal plants: cure for the $21^{\text {st }}$ century: Biodiversity, conservation and utilization of medicinal plants: Proceedings of the seminar UPM, Serdang, Malaysia, 162-170.

Newman, D.J. and G.M. Cragg, (2007). Natural products as sources of new drugs over the last 25 years. J. Natural Prod 70: 461-77.

Nikkitha, J.P. (1999). Ethno-medico-botanical studies and antibacterial activity on medicinal plants of 'Irular adivasis' Attukkal Village, Thondamuthur 
block, Coimbatore district, Tamil Nadu. M. Phil Dissertation, Bharathiar University, Coimbatore, Tamil Nadu.

Palanisamy, K. (1993). Ethnobotany of Irulars from Kallar, Mettupalayam taluk, Coimbatore district, M Sc. Dissertation, Kongunadu Arts and Science College, Coimbatore, Tamil Nadu.

Parthipan, M., V. Aravindhan and A. Rajendran, (2011). Medico-botanical Study of Yercaud Hills in the Eastern Ghats of Tamil Nadu, India. Ancient Sci. Life 30(4): 104-109.
Paulsamy, S. (2011). Maruthamalai hills of Western Ghats, Coimbatore District, and Tamil Nadu. A potential ecosystem for medicinal plants. J. Res. Plant Sci 1: 12-26.

Rajadurai, M., V.G. Vidhya, M. Ramya and A. Bhaskar, (2009). Ethnomedicinal plants used by the traditional healers of Pachamalai Hills, Tamil Nadu, India. Ethno-Med 3(1): 39- 41.

Robert, H. and B. John, (1983). Traditional medicine and health care coverage. WHO, 326-327.

Roosita, R., C.M. Kusharto, M. Sekiyama, Y. Fachrurozi and R. Ohtsuka, (2008). 